\title{
MODELS OF INNOVATION INSTITUTIONS MANAGEMENT IN THE UNIVERSITY ECOSYSTEM
}

\author{
Hubert PACHCIAREK ${ }^{1 *}$, Malwina SZAREK ${ }^{2}$, Daniel WIATEREK ${ }^{3}$ \\ ${ }^{1}$ University of Szczecin; malwina.szarek@usz.edu.pl, ORCID: 0000-0003-0355-9275 \\ ${ }^{2}$ University of Szczecin; hubert.pachciarek@usz.edu.pl, ORCID: 0000-0003-0582-1740 \\ ${ }^{3}$ Innovation Centre of the Maritime University in Szczecin; d.wiaterek@innoam.pl \\ * Correspondence author
}

Purpose: The key driver to discuss the topic is a research gap as regards the management of SPEs and TTCs in the innovation ecosystem.

Design/methodology/approach: The article discusses a university innovation ecosystem in Poland. It also provides a comparative analysis of the functional management models in the innovation ecosystem with the coexistence of TTCs and SPEs with: 1) separated management functions, and 2) a personal union, i.e. the same person managing TTC and SPE. The following research methods have been used: a participatory observation, a focus group discussion to analyse the collected research material and draw conclusions.

Findings: The article presents major benefits and risks for TTCs and SPEs, benefits and risks that are related to specific management models applied in entities responsible for technology transfer and commercialization. It is not possible to indicate which of the two TTC and SPE management models is better or more efficient, since advantages can be achieved with both of the models, provided specific conditions are met. Those advantages are mainly related to the cooperation with the social and business environment of a university.

Research limitations/implications: The recommendations contribute to a further discussion on the role of TTCs and SPEs and their relations in the innovation ecosystem, as well as efficient management and assessment of technology transfer institutions.

Practical implications: The article provides recommendations for dealing with those risks in each of models identified.

Originality/value: The article fills a research gap as regards the management of SPEs and TTCs in the innovation ecosystem.

Keywords: university innovation ecosystem, Technology Transfer Centre, university-based SPE.

Category of the paper: case study. 


\section{Introduction}

The term "innovation ecosystem" has become popular and used in the industry, universities and by the state administration (Oh et al., 2016). An analogy to the ecosystem was borrowed from the science of biology and it is a metaphoric description of interactions between a large number of players, as well as those players and their surrounding (Fransman, 2014, Autio, and Thomas, 2014). The term was first used in the literature on economics in the mid-nineties in the context of a "business ecosystem", which comprised business communities acting together and bringing innovation to the market (Moor, 1993).

In the science of management, the term of "ecosystem" is used while referring to a network of operators who collaborate and compete at the same time (Gobble, 2014, Autio, and Thomas, 2014). The concept of an "innovation ecosystem" stresses the evolutionary nature of the system and its development through innovation. An ecosystem links groups of entities that create and implement innovation based on a symbiotic relationship (Fransman, 2014). A comprehensive approach to the issue shows the complexity of the innovation process from the generation of knowledge in scientific organizations to its transfer and commercialization in the industry (Russell et al., 2011).

The innovation ecosystem can be seen also from the point of view of national or regional innovation policies (Blażlak, 2016). In such a context, it is a collection of comprehensive solutions (ideas, organizations, policies and regulations) facilitating cooperation between public and private sectors, and thus the creation of relevant conditions for the transfer of knowledge and generation of new solutions that can be deployed on the market.

Components of the innovation ecosystem fit into the triple helix model (Etzkowitz, and Leydesdorff, 2000) and they can be divided into three groups:

1. Science organizations (universities, R\&D departments).

2. Business organizations (SMEs and large enterprises).

3. State organizations (public administration bodies at central and local levels).

The above three groups should be supplemented by the fourth one, namely business environment institutions, which are created by $R \& D$, public sector and private sector entities. They include loan funds and credit guarantee funds, training and consultancy centres, and business incubators.

The structure of the innovation ecosystem is affected by conditions in a given region in which the ecosystem is based, as well as key stakeholders and relationships between them. Universal participants (actors) of the innovation ecosystem include (Cukier et al., 2016):

- public and private research organizations which are a source of new knowledge,

- start-ups established as a result of commercialization of knowledge and technology,

- companies which create and deploy new products, services and processes, 
- funding partners, including financial institutions and investors providing financing for companies and start-ups,

- "pool of talents" moving between organizations, sectors and regions,

- business environment institutions, e.g. business incubators, training and consultancy centres,

- governmental institutions stimulating or constraining innovation, and

- "innovation culture" which refers to beliefs and values prevailing in a society in relation to enterprise and innovation.

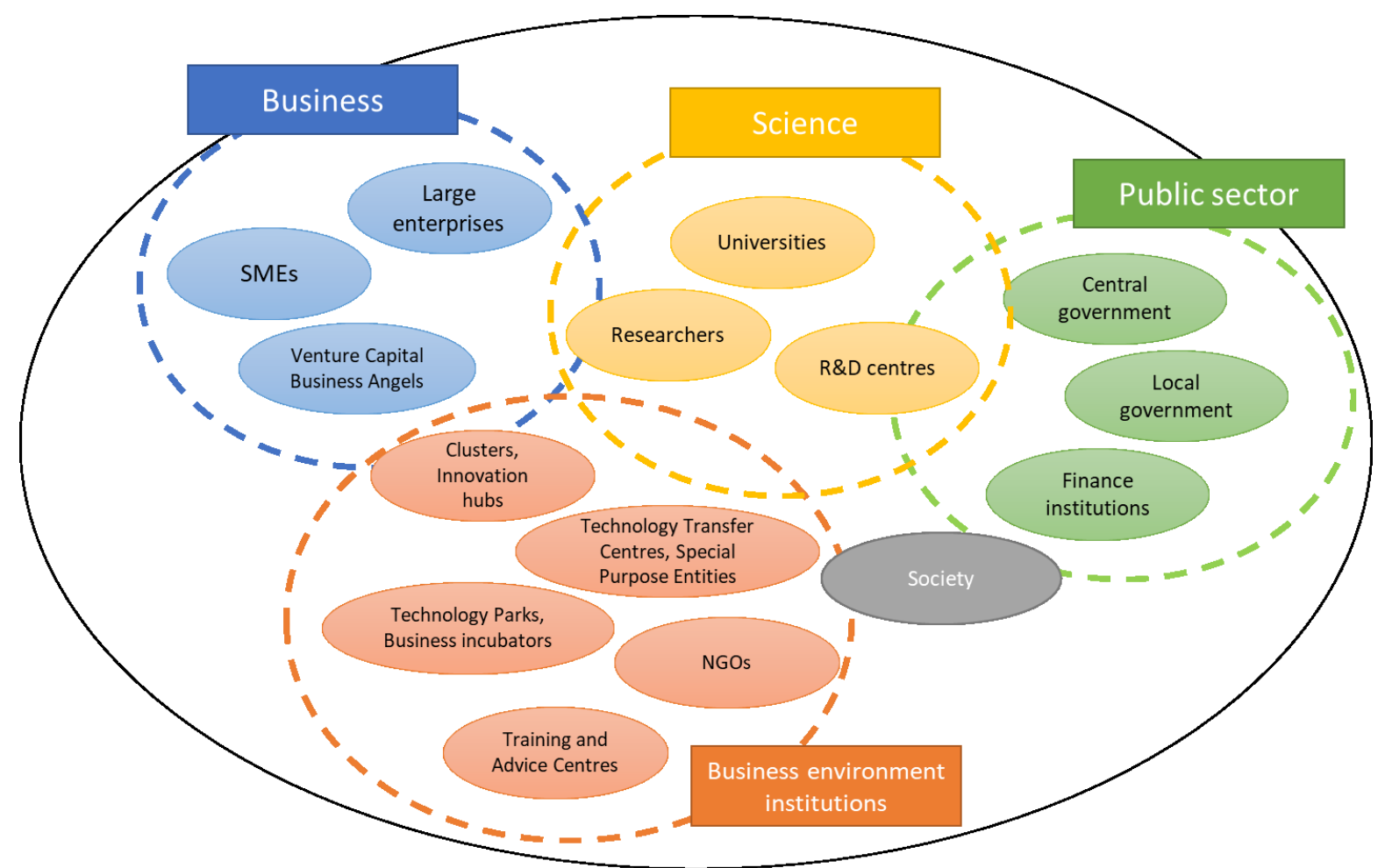

Figure 1. Participants of the innovation ecosystem. Source: the author.

Figure 1 shows a general model in which actors of the innovation ecosystem represent individual spheres, i.e. public, private, science or business, are involved in mutual interactions to generate new knowledge and deploy it on the market.

In recent years, when innovation has been so important for economic growth (Narodowy Bank Polski, 2016), the development of innovation ecosystems is increasingly important, in particular at the regional level. This is the result of major changes, such as globalization, digitization, climate change and social challenges that require comprehensive solutions and involvement of many different parties. Universities play a strategic role in the development of innovation (Reichert, 2019; OECD, 2015). In the 1980s and 1990s, business activity at universities began to grow in such countries as the United States, Canada, United Kingdom, Germany, France, Italy and Sweden (Kardas, 2016). It was the beginning of the idea of the third generation university (Wissema, 2009). The transformation of science in Poland, which has 
been observed in recent years, especially after the adoption of the "Constitution for Science"1, is designed to boost the cooperation between science and business.

From the point of view of universities, the following entities play a special role in their innovation ecosystem: Technology Transfer Centers (TTC) and university-based special purpose entities (SPE), which are directly related to the university and constitute a bridge between science and business. The establishing by the university of bodies responsible for technology transfer and commercialization of R\&D outcomes create vast opportunities for the cooperation with business. In this respect, although the organization of commercialization and technology transfer through TTCs and SPEs and the cooperation between these entities seem to be particularly important, they seem to be increasingly problematic for people managing those entities.

The aim of the article is to provide a comparative analysis of management models applied in university-based innovation ecosystem institutions. The authors have compared the coexistence of TTCs and SPEs in two situations: 1) when different people manage them and 2) when the same person manages both entities. The key driver to discuss the topic is a research gap as regards the management of SPEs and TTCs in the innovation ecosystem. The article presents major benefits and risks for TTCs and SPEs, benefits and risks that are related to specific management models applied in entities responsible for technology transfer and commercialization. Additionally, the article provides recommendations for dealing with those risks in each of models identified and indicates directions of future research.

\section{Location of TTCs and SPEs in the innovation ecosystem}

The ecosystem consists of a unique set of entities and interactions, which is constantly evolving, and each entity has its own role to play (Volkokari 2015). The implementation of the third mission goal of a university, namely the commercialization of research, has increased the importance of centres for technology transfer and special purpose entities. These entities support the management of intellectual property rights owned by universities according to market requirements. Figure 2 shows the location of the TTC and SPE in the university innovation ecosystem structure.

\footnotetext{
${ }^{1}$ Higher Education and Science Law of 20 July 2018.
} 


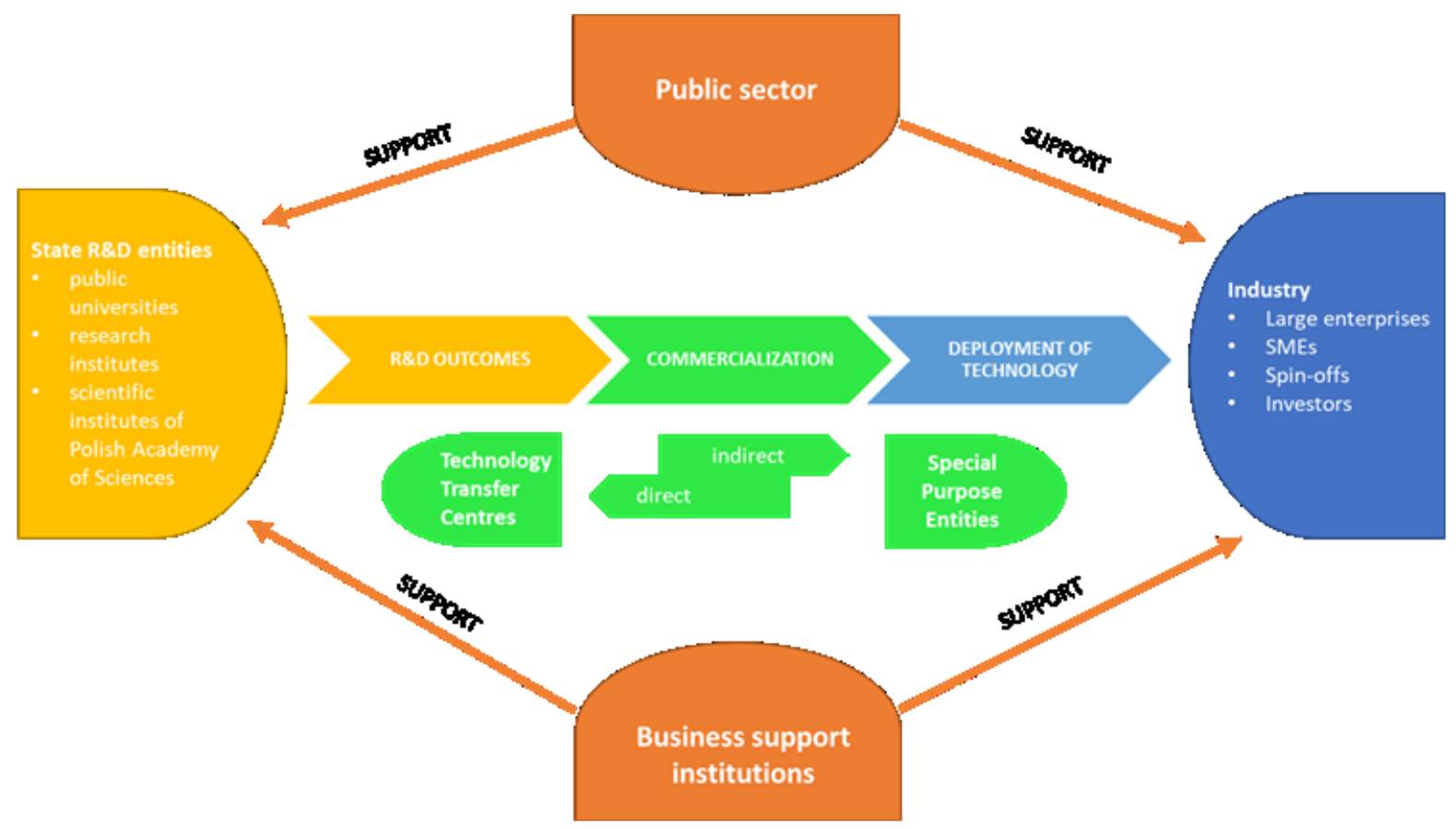

Figure 2. University innovation ecosystem model. Source: the author.

The objective of the TTC is to stimulate innovation at universities and enable the use of intellectual potential of the research staff (Narodowa Izba Kontroli, 2016). First TTCs in Poland were created in the second half of the 1990s and resulted from bottom-up initiatives of researchers and university authorities. Legislative changes were introduced with the law of 2005 on the operation of TTCs (Kardas, 2015). The main area of TTC activity is the direct commercialization which involves the sale of research outcomes, know-how related to these outcomes and providing these outcomes or know-how for use, in particular on the basis of license, rental and lease agreements (Article 2 paragraph 1 point 35 of Higher Education Law). TTCs offer information and consultation functions for researchers interested in technology transfer.

To proceed with an indirect commercialization, namely the take-over or acquisition of shares or stocks in companies to implement or to prepare for the implementation of R\&D or know-how related to it (Article 2 paragraph 1 point 36 of Higher Education Law), the rector of a university has to establish a special purpose entity (SPE). According to the law, single-partner companies established by public or private universities (Article 86a (1) of Higher Education Law) allow universities to run business activity according to market principles. Therefore, main advantages of the solution include:

- greater operational flexibility since an SPE does not have to comply with the public procurement law;

- an SPE is treated as an equal business partner, as attested by its manager who has necessary knowledge of business and science alike;

- financial and organizational independence, which translates into flexibility in decision making and greater openness to take risk. 
Based on a separate agreement, the rector may vest in an SPE rights to proceed with direct commercialization of R\&D outcomes or know-how, which means in practice that an SPE can take over competences of the technology transfer centre. According to the report by the National Audit Office (Narodowa Izba Kontroli, 2019), in the period of 2013-2017, university-based SPEs had low efficiency of knowledge and technology transfer. This was confirmed by the report on the SPIN-TECH project examining SPEs in 2012-2016 (Narodowe Centrum Badań i Rozwoju, 2016).

Before 2014, TTCs could have various legal forms because, next to university SPEs, they were established as commercial businesses or foundations. Since universities were allowed to establish special purpose entities, TTCs have been created at the institutional level. In 2014, changes in the law on the TTCs and SPEs aimed to clarify tasks attributable to TTCs and the division of competences between TTCs and SPEs (Table 1).

Table 1.

Objectives of university organizational units related to commercialization

\begin{tabular}{|c|c|l|l|}
\hline \multirow{2}{*}{ Units } & \multicolumn{2}{|c|}{ Higher Education Law } \\
\cline { 2 - 4 } & \multicolumn{2}{|c|}{$\mathbf{2 0 0 5}$} & \multicolumn{2}{|c|}{$\mathbf{2 0 1 1}$} & \multicolumn{2}{|c|}{$\begin{array}{c}\text { 2014 } \\
\text { Transfer Centers }\end{array}$} & Sales or free transfer R\&D outcomes to the economy & $\begin{array}{l}\text { Direct commercialization, } \\
\text { including sales or license to use } \\
\text { R\&D outcomes or know-how }\end{array}$ \\
\hline $\begin{array}{c}\text { University- } \\
\text { based special } \\
\text { purpose entities }\end{array}$ & - & $\begin{array}{l}\text { Commercialization of } \\
\text { R\&D outcomes }\end{array}$ & $\begin{array}{l}\text { Indirect commercialization, } \\
\text { including spin-offs } \\
\text { Optional direct } \\
\text { commercialization }\end{array}$ \\
\hline
\end{tabular}

Source: based on Kardas 2016.

Universities in the country vary regarding their organizational structures related to knowledge transfer and commercialization. Most of them have formed general-purpose university entities, such as technology transfer centres and/or independent operators responsible for commercialization, known as special purpose entities. Depending on their needs, while proceeding towards indirect commercialization and potentially creating spin offs, universities started to establish SPEs. According to the current legislation, technology transfer centres may not implement tasks that are reserved for special purpose entities, whereas a reverse situation, including direct commercialization, is possible. Therefore, certain universities establish civil law companies only with the aim to provide both indirect and direct commercialization (e.g. UMED Sp. z o.o., SYNERGY-WUM Sp. z o.o.). In many cases, both types of entities have sufficient space to operate, i.e. TTCs and SPEs (e.g. EXCENTO Sp. z o.o. and Centre of Knowledge and Technology Transfer at Gdańsk University of Technology, Krakow Centre of Innovative Technology INNOAGH Sp. z o.o. and Technology Transfer Centre at AGH University). In some instances, the civil law company plays the role of a special technology transfer centre responsible for the management of intellectual property rights owned by the university, e.g. Technology Transfer Centre of Łódź University of Technology or Technology Transfer Centre INTech Sp. z o.o (Szarek, and Pachciarek, 2019). 
So far, as it appears from reports (Narodowa Izba Kontroli, 2018; Narodowe Centrum Badań i Rozwoju, 2018; Bakowski and Marzewska, 2018), both TTCs and SPEs were not an effective method of commercialization and technology transfer to the economy. It means that these organizations have failed to take advantage of their potential and face numerous challenges, such as:

- shortage of skilled managers and brokers,

- competition between TTCs and SPEs (in particular when they implement tasks that are not their main area of competence, such as counseling or research infrastructure management), which results from the lack of defining the formal roles of SPEs and TTCs within the university structure, and poor division or coordination of competences between these entities.

- absence of research resources with commercial deployment potential,

- shortage of comprehensive incentives for researchers and companies to engage in R\&D,

- poor match of TTC and SPE offer to the market demand,

- TTCs and SPEs are forced to run business that is not related to commercialization to maintain their financial liquidity and human resources, and

- dependence on support from their universities.

\section{Research Methodology}

The main purpose of the research strategy, and consequently test methods, has been to gain an in-depth understanding of the subject matter and the goal of research. It should be noted that some of key conditions for the application of the qualitative analysis include a full and comprehensive understanding of processes and capturing of practical experience of entities examined in their natural environment (Czernek, 2016). The above is very relevant for the purpose of this article. A comparative analysis in the complex subject of research, which includes management processes in technology transfer institutions, requires a thorough understanding, whereas the practical experience of the authors in managing of TTCs and SPEs supports the use of research methods, e.g. participatory observation and focus discussion in order to analyse research materials. Research materials from participatory observation was collected for a period of two years, whereas a series of focus discussions was held between June and October 2019. 


\section{Comparative analysis based on observation}

The main area of authors' interest is the coexistence of technology transfer centres and special purpose entities in universities or research institutions in Poland, in particular changes in their management structures. In the Polish context, two approaches can be observed, namely the separation of management functions between TTCs and SPEs and the appointment of the incumbent TTC director to the position of the SPE chairman (i.e. personal union). The most common motives to create such a personal union are:

- shortage of staff with sufficient competences to manage institutions focusing on the cooperation between science and business,

- centralization of science-business cooperation, especially when universities have just started their activity in this area,

- lack of sufficient number of marketable R\&D projects to support employment in two separate functions which coincides with intensive workload related to the cooperation between science and business,

- need to develop staff members capable of managing a TTC or an SPE - in such instances, the personal union is usually temporary, and

- need for coordinated collaboration between science and business, in particular when universities vary significantly technology-wise.

Considering the above conditions, we may conclude that the personal union may be temporary or permanent. While the temporary status is usually the result of staff shortages and the search for relevant candidates or the need to re-train the existing staff members to develop their managerial skills, a decision to create a permanent personal union stems from the implementation of the science-business collaboration strategy. Table 2 presents conclusions of a focus discussion and observations made by the authors regarding the operation of TTCs and SPEs within the two different models. ${ }^{2}$ Advantages and disadvantages presented are based on the analysis and risks identified. However, this does not mean that they always appear in specific cases described by the authors. It should be emphasized that the majority of disadvantages could be avoided once their awareness is raised and remedial actions taken, as presented in the further part of the article.

\footnotetext{
${ }^{2}$ Daniel Wiaterek is the President of the Innovation Centre of the Maritime University in Szczecin, an SPE established by the Maritime University in Szczecin, whereas Hubert Pachciarek plays the role of the Director of the Technology Transfer Centre of the Pomeranian Medical University in Szczecin and the President of the Centre of Innovative Medical Technologies, Pomeranian Medical University in Szczecin.
} 
Table 2.

Comparative analysis of management models in the university innovation ecosystem

\begin{tabular}{|c|c|}
\hline Personal union & TTC and SPE managerial functions separated \\
\hline \multicolumn{2}{|c|}{ Advantages } \\
\hline $\begin{array}{l}\text { Eliminated risk of competition between TTC and } \\
\text { SPE for outcomes of research, collaboration with } \\
\text { research teams and representatives of the university } \\
\text { social and business community. }\end{array}$ & $\begin{array}{l}\text { The manager more focused on the development of } \\
\text { TTC or SPE and the implementation of strategic } \\
\text { goals. }\end{array}$ \\
\hline $\begin{array}{l}\text { Synergy effect due to close cooperation of TTC and } \\
\text { SPE teams, and consequently the improved efficiency } \\
\text { of technology transfer and knowledge } \\
\text { commercialization. }\end{array}$ & $\begin{array}{l}\text { Concentration of the development of managerial } \\
\text { skills relevant for TTC or SPE, while taking into } \\
\text { account specific nature of a university-based } \\
\text { company or an administrative unit and commercial } \\
\text { law. }\end{array}$ \\
\hline $\begin{array}{l}\text { Chance to optimize the legal form of an organization } \\
\text { responsible for technology commercialization and } \\
\text { commercialization paths, since decision-making } \\
\text { power remains within one function. }\end{array}$ & $\begin{array}{l}\text { Expanding possibilities to commercialize research } \\
\text { outcomes by the separation of the offer and personnel } \\
\text { in TTC and SPE. }\end{array}$ \\
\hline $\begin{array}{l}\text { Centralization of knowledge on technology transfer } \\
\text { and commercialization at an university. }\end{array}$ & $\begin{array}{l}\text { Chance to upgrade TTC and SPE competences within } \\
\text { their respective areas of interest, including direct } \\
\text { commercialization and indirect commercialization. }\end{array}$ \\
\hline \multicolumn{2}{|c|}{ Disadvantages } \\
\hline $\begin{array}{l}\text { "Dual loyalty" issue, since managers need to choose } \\
\text { which entity should be responsible for technology } \\
\text { transfer and which for commercialization (TTC or } \\
\text { SPE). In case both entities, representing the } \\
\text { university innovation ecosystem, can run the process, } \\
\text { managers face the dilemma of being loyal towards } \\
\text { university or the SPE while deciding on } \\
\text { commercialization, especially when this is not } \\
\text { important for the process itself. }\end{array}$ & $\begin{array}{l}\text { Competition between TTC and SPE regarding } \\
\text { technology, teams of researchers, enterprises and } \\
\text { investors cooperating with the university. }\end{array}$ \\
\hline $\begin{array}{l}\text { Managers find it hard to focus on one entity only, } \\
\text { which may lead to an organizational chaos. }\end{array}$ & $\begin{array}{l}\text { Overlapping competences regarding transfer of } \\
\text { technology and commercialization of knowledge. }\end{array}$ \\
\hline $\begin{array}{l}\text { Difficulty in dividing working time between TTC and } \\
\text { SPE from formal, organizational and economic points } \\
\text { of view. }\end{array}$ & $\begin{array}{l}\text { Shortage of TTC engagement in enhancing of the } \\
\text { technology readiness level (TRL) regarding those } \\
\text { technologies that are going to be transferred to the } \\
\text { SPE for commercialization. Therefore, SPEs receive } \\
\text { technologies that are not ready to be indirectly } \\
\text { commercialized. }\end{array}$ \\
\hline $\begin{array}{l}\text { Risk of demotivation, in case the manager is } \\
\text { overburdened with responsibilities related to } \\
\text { technology transfer and at the same time the person } \\
\text { has to take care of SPE financial figures. }\end{array}$ & $\begin{array}{l}\text { TTC and SPE compete for the access to those areas } \\
\text { of technology transfer which can be the most } \\
\text { beneficial profit-wise rather than required by law } \\
\text { (commissioned projects for business, expert opinions, } \\
\text { externally funded projects). }\end{array}$ \\
\hline $\begin{array}{l}\text { Managers are guided by the current need of } \\
\text { supporting TTC or SPE instead concentrate on } \\
\text { client's interests. Then, they direct the client to a } \\
\text { specific entity instead optimizing the legal form of a } \\
\text { project. }\end{array}$ & $\begin{array}{l}\text { Creators may find it difficult to determine who } \\
\text { should they contact to commercialize their research } \\
\text { findings, and in consequence, they may choose the } \\
\text { most convenient solution or people they know best. }\end{array}$ \\
\hline
\end{tabular}

Source: own materials.

According to the table, it is not possible to determine which of the management models is the best and the most effective in the university innovation ecosystem. In both instances, advantages defined can materialise in specific conditions only. For certain, substantial experience of the university and a large number of technology transfer and $R \& D$ commercialization projects predispose the university to separate managerial functions, while the personal union works best in a less mature university environment. Important factors include 
not only knowledge and experience of TTC and SPE managers and employees, but also awareness and readiness of researchers to cooperate. Yet another very important factor is the number of business entities, such as investors and entrepreneurs, in the university ecosystem that might be interested in collaboration. Therefore, for certain, the implementation of a specific management model in knowledge and technology transfer institutions necessitate informed decisions based on clearly defined goals related to the collaboration with the relevant social and business community.

From the point of view of disadvantages attributable to the management models, it is important to determine how those can be avoided. If it is not possible, activities should be defined to mitigate their impact on TTC and SPE. It seems that, regardless of the model, the crucial factor determining the collaboration between TTC and SPE is to specify competences and tasks of the two entities. Once such guidelines are listed in a written contract, a number of disadvantages can be avoided related to overlapping competences, no TTC engagement in enhancing the TRL of research outcomes to be commercialized, and SPE engagement in commercialization itself. At the same time, in the case of a personal union, the manager is empowered to allocate specific projects to relevant technology transfer institutions. Moreover, the contract may create a foundation to develop comprehensive collaboration between TTC and SPE despite personal factors. It seems that the most desired division of competences between TTC and SPE is to make the TTC responsible for collaboration with researchers to improve the TRL, and the SPE responsible for commercialization of ready-made solutions. The collaboration may be promoted when TTC run R\&D projects focus on actual market needs determined based on SPE market relations and contacts with investors and entrepreneurs interested in purchasing or commercializing project outcomes. Yet another factor is to develop a system of information exchange between TTC and SPE, as well as between technology transfer institutions and researchers, and technology transfer institutions and their market environment. Needless to say, collaboration requires efficient communication. However, it is possible to identify a number of conflict areas due to personal reasons (creator and innovation broker), formal factors (preferred entity for commercialization), economic factors (cost related to technology transfer, including indirect costs and university margins) and organizational ones (efficiency and time needed to make decisions). For this reason, the implementation of project management tools should promote joint definition of goals and improvement in communication between parties concerned. This enhances success of the entire process. At the same time, maintained consultations with scientific units through R\&D audits can provide excellent opportunities to start cooperation with technology transfer entities at a university. Another mechanism is to set up workshops for researchers, $\mathrm{PhD}$ and other students, and use regular meetings of university bodies, such as institute and scientific councils to promote long-term cooperation with creators and building awareness of roles played by TTCs and SPEs. 
A separate issue is the collaboration between technology transfer leaders (i.e. scientists experienced in collaboration with society and business community) who, through their ordinary teaching and research work, maintain relations with other scientists not so easily accessible for technology transfer institutions. Technology transfer leaders may facilitate contacts with creators and, consequently, enable to build trust. The TTC director should be responsible for networking with technology transfer leaders from various R\&D institutions, whereas the SPE president should focus on developing cooperation with external organizations. An important factor is also financial stability of technology transfer institutions. The stability enables the TTC to focus on supporting creators and enhancing the TRL and offering legal protection for their inventions. On the other hand, the financial stability of the SPE enables to implement commercialization projects that, although risky, have the highest market potential, instead of safe and little innovative business activity to secure basic funds for the institution concerned. In the case of a personal union, this factor should enable the manager to focus on the primary business of the entity, whereas with the separation of those functions, the pressure is diminished to compete for collaboration with the most promising research teams or high potential projects.

\section{Summary}

Changes observed in universities and their employees support collaboration between universities and their social and business communities. For this reason, universities establish various institutions whose primary goal is to promote knowledge and technology transfer, as well as commercialization of R\&D outcomes. Usually, they establish Technology Transfer Centres, and recently also Special Purpose Entities. The latter are established to support TTCs and promote technology transfer and commercialization, since TTC's competences and capability may turn out to be insufficient. Sometimes SPEs take over TTC functions, which ultimately leads to the liquidation of TTCs. However, customarily TTCs and SPEs operate in parallel complementing their services offered to creators, researchers and businesses. In the latter case, the most prevalent model involves the separation of managerial functions between the TTC director and SPE president. Sometimes, however, the two functions are merged to create a personal union, and the same person manages the TTC and the SPE. The experience of SPEs in Poland is definitely too limited to decide which of the models is better. Nevertheless, conclusions based on the discussion and observation of advantages and disadvantages of the models show that each one of them can improve the operation of the innovation ecosystem provided specific conditions are met. This depends on the internal complexity of a university, number of deployable project outcomes, awareness of scientists regarding the protection of intellectual property and their experience in technology transfer, as well as access to skilled managers and brokers. Recommendations concerning how to deal 
with disadvantages enable to avoid or mitigate risk in each model. For certain, clearly defined cooperation rules, efficient communication and financial stability strengthen the university innovation ecosystem in each of the technology transfer management models. The recommendations contribute to a further discussion on the role of TTCs and SPEs and their relations in the innovation ecosystem, as well as efficient management and assessment of technology transfer institutions.

\section{References}

1. Autio, E., Thomas, L.D.W. (2014). Innovation Ecosystems: Implications for Innovation Management? In: M. Dodgson, D.M. Gann, N. Phillips (Eds.), The Oxford Handbook of Innovation Management. Oxford, UK: Oxford University Press.

2. Bąkowski, A., Marzewska, M. (Eds.) (2018). Ośrodki Innowacji i Przedsiębiorczości $w$ Polsce. Raport 2018. Poznań/Warsaw: Stowarzyszenie Organizatorów Ośrodków Innowacji i Przedsiębiorczości w Polsce.

3. Blażlak, R. (2016). Innowacyjność przedsiębiorstw, a problematyka transferu technologii. Zeszyty Naukowe Politechniki Częstochowskiej Zarzadzanie, 22, pp. 147-155, doi: 10.17512/znpcz.2016.2.13

4. Cukier, W., Stolarik, K., Ngwenyama, O., Elmi, M. (2016). Mapping The Innovation Ecosystem in Eastern Ontario. Towards an inclusive Canadian innovation strategy. Toronto: Institute for Innovation \& Technology Management.

5. Czernek, K. (2016).Wprowadzenie do badań jakościowych w naukach o zarządzaniu. In: W. Czakon (Ed.), Podstawy metodologii badań w naukach o zarządzaniu. Warszawa: Wydawnictwo Nieoczywiste.

6. Etzkowitz, H., Leydesdorff, L. (2000). The dynamics of innovation: from National Systems and "Mode 2" to a Triple Helix of university-industry-government relations. Research Policy, 29(2), pp. 109-123, doi: 10.1016/S0048-7333(99)00055-4.

7. Fransman, M. (2014). Models of Innovation in Global ICT Firms: The Emerging Global Innovation Ecosystems. JRC Science and Policy Report, University of Edinburgh.

8. Gobble, M.M. (2014). Charting the innovation ecosystem. Research-Technology Management, 57(4), pp. 55-59.

9. Kardas, M. (2016). Organizational Aspects of Knowledge Transfer and Commercialization of Public Research at Polish Universities. Problemy Eksploatacji-Maintenance Problems, 2, pp. 59-69.

10. Moore, J.F. (1993). Predators and prey: a new ecology of competition. Harvard Business Review, 71, pp. 75-86. 
11. Narodowa Izba Kontroli (2016). Komercjalizacja wyników badań naukowych. Warsaw: Departament Nauki, Oświaty i Dziedzictwa Narodowego.

12. Narodowe Centrum Badań i Rozwoju (2016). Diagnoza stanu transferu technologii za pośrednictwem spótek celowych wykorzystująca dotychczasowe doświadczenia z realizacji programu SPIN-TECH. Warsaw.

13. Narodowy Bank Polski (2016). Potencjat innowacyjny gospodarki: uwarunkowania, determinanty, perspektywy. Warsaw.

14. OECD (2015). Innovation Strategy. Paris.

15. Oh, D.S., Phillips, F., Park, S., \& Lee, E. (2016). Innovation ecosystems: A critical examination. Technovation, 54, pp. 1-6.

16. Reichert, S. (2019). The Role of Universities in Regional Innovation Ecosystems. Brussels: European University Association.

17. Russell, M.G., Still, K., Huhtamaki, J., Yu, C., Runens, N. (11-14 July 2011). Transforming Innovation Ecosystems through Shared Vision and Network Orchestration. In Proceedings of the Triple Helix IX International Conference: "Silicon Valley: Global Model or Unique Anomaly?", Stanford. Retrieved from http://www.leydesdorff.net/th9/3NWAFYZH9 Russell.pdf, 11.10.2019.

18. Szarek, M., Pachciarek, H. (2019). Spółka celowa uczelni - wsparcie dialogu między światem nauki i biznesu. Przedsiębiorczość i Zarządzanie, 20(6), pp. 253-266.

19. The amendment of 18 March 2011 to the Higher Education Law, Law on scientific degrees and titles and degrees and titles in arts, and amendment of certain other laws.

20. The Higher Education Law of 20 July 2018.

21. Volkokari, K. (2015). Business, Innovation, and Knowledge. Ecosystems: How They Differ and How to Survive and Thrive within Them. Technology Innovation Management Review, 5(8), pp. 17-24. Retrieved from https://timreview.ca/article/919, 11.10.2019.

22. Wissema, J.G. (2009). Uniwersytet Trzeciej Generacji. Uczelnia XXI wieku. Zębice: Wydawnictwo Zante. 